J. Dairy Sci. 98:2409-2418

http://dx.doi.org/10.3168/jds.2014-8734

(C) American Dairy Science Association ${ }^{\circledR}, 2015$.

\title{
The somatotropic axis during the physiological estrus cycle in dairy heifers-Effect on hepatic expression of GHR and SOCS2
}

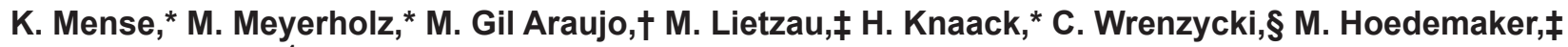 \\ and $M$. Piechotta*1 \\ *Endocrinology Laboratory, Clinic for Cattle, University of Veterinary Medicine, 30173 Hannover, Germany \\ †Department of Animal Biology, Faculty of Veterinary Science, University of Zulia, Maracaibo, Zulia 44011, Venezuela \\ $\ddagger$ Clinic for Cattle, University of Veterinary Medicine, 30173 Hannover, Germany \\ §Clinic for Obstetrics, Gynecology and Andrology of Large and Small Animals, Faculty of Veterinary Medicine, Justus-Liebig-University, \\ 35392 Giessen, Germany
}

\begin{abstract}
Pituitary growth hormone $(\mathrm{GH})$ release and hepatic insulin-like growth factor-I (IGF-I) production increase after an injection of $17 \beta$-estradiol $\left(\mathrm{E}_{2}\right)$ in ovariectomized dairy cattle. However, whether endogenous sexual steroid hormones also influence the hepatic GH receptor (GHR) signaling pathway during a physiological estrus cycle remains unclear. The aim of this study was to analyze the hepatic GHR signaling pathway during the luteal phase and after a period of increased $\mathrm{E}_{2}$ concentrations (after ovulation) as well as in 7 heifers before ovulation. Ovarian ultrasounds were performed daily during repeated physiological cycles $(\mathrm{n}=56)$ of 30 Holstein Friesian heifers to determine ovulation [before ovulation ( $\mathrm{n}=7, \mathrm{bOv})$ and after ovulation $24-60 \mathrm{~h}$ after the appearance of estrus signs $(\mathrm{n}=49, \mathrm{aOv})]$ and luteal phase (CLP; d $12 \pm 1$ after ovulation). Blood samples and liver biopsies were obtained, and blood concentrations of $\mathrm{E}_{2}, \mathrm{P}_{4}$, insulin-like growth factor (IGF)-I, IGFII, and GH were measured. In the liver biopsies, we determined mRNA expression of the estrogen receptor $\alpha$ $(E R \alpha), G H R$, Janus kinase 2 (JAK2), signal transducer and activator of transcription 5B (STAT5B), suppressor of cytokine signaling $(S O C S)_{2} 2$ and 3, IGF-I, and $I G F-I I$ by quantitative reverse transcription-PCR. The concentration of $\mathrm{E}_{2}$ was higher bOv than aOv and CLP, as expected. The concentrations of IGF-I and GH were higher bOv and aOv compared with CLP. In contrast, concentrations of IGF-II were lower aOv compared with bOv and CLP. The mRNA expression of GHR was higher in liver biopsies obtained bOv compared with aOv and CLP. Notably, the expression of SOCS2 was higher bOv than aOv and in the CLP. Increased hepatic expression of SOCS2 during estrus was detectable when IGF-I concentrations were high; this result
\end{abstract}

Received August 12, 2014.

Accepted January 5, 2015.

${ }^{1}$ Corresponding author: marion.piechotta@tiho-hannover.de might indicate that SOCS2 expression attenuates the $G H R$ signal transduction pathway during the phase of increased pituitary GH release. In conclusion, hepatic GHR and SOCS2 mRNA expression appeared to be promptly and sensitively regulated by increased $\mathrm{E}_{2}$ levels before ovulation of dairy heifers.

Key words: growth hormone, insulin-like growth factor, estrus cycle, suppressors of cytokine signaling, growth hormone receptor

\section{INTRODUCTION}

The somatotropic axis is a key endocrine factor not only important for growth, but also appears to be a link between an adequate metabolic adaption to lactation and sufficient reproductive performance in dairy cows (Breier, 1999; Lucy et al., 2001; Zhu et al., 2001; Armstrong et al., 2003; Wathes, 2012). The pulsatile release of growth hormone $(\mathbf{G H})$ from the pituitary is regulated through the release of growth hormone inhibiting hormone and growth hormone releasing hormone (Tuggle and Trenkle, 1996), and GH binds to its specific receptors (GHR; Baumann, 2001), which is expressed at the highest density in the liver (Renaville et al., 2002). The binding of GH to its receptor induces an intracellular Jak-Stat signaling pathway (Figure 1; Herrington and Carter-Su, 2001), which results in the transcription of IGF-I as well as other genes (Bichell et al., 1992; Rajaram et al., 1997). The effects of GH on metabolism and reproduction can be divided into the direct (e.g., increased hepatic gluconeogenesis and protein synthesis, reduced lipogenesis and insulin sensitivity) and indirect effects, mediated by the production of IGF (Renaville et al., 2002). Both IGF-I and IGF-II are essential for cell growth, intrauterine development, and postnatal growth, and they regulate metabolism by having GH antagonistic effects on glucose metabolism (Moses et al., 1980; Gourmelen et al., 1984; Lassarre et al., 1991; Grimberg and Cohen, 2000; Romano et al., 2001; Valentinis and Baserga, 2001). Some studies 
support that the somatotropic axis is directly affected by sexual steroid hormones, such as progesterone $\left(\mathbf{P}_{4}\right)$ and 173-estradiol $\left(\mathbf{E}_{2}\right.$; Kawashima et al., 2007b; Colak et al., 2011), which could be caused by a direct effect of these hormones on pituitary GH secretion, but steroid hormones may also influence the hepatic GH signaling pathway. Colak et al. (2011) described an increase in GH and IGF-I blood concentration and an increase in hepatic GHR mRNA expression in ovariectomized cattle treated with $\mathrm{E}_{2}$. Furthermore, Kawashima et al. (2007b) observed an increase in IGF-I blood concentration during the follicular phase of cows. A similar result was detected in cyclic sheep (Spicer et al., 1993) and goats (Yonezawa et al., 2005). However, in a study by Alvarez et al. (2000), no difference in IGF-I or IGF-II blood concentration could be detected in cows during the follicular phase. None of the studies in cyclic ruminants analyzed the particular components of the hepatic GHR signaling pathway. Moreover, none of the studies took samples after long periods of increased $\mathrm{E}_{2}$ levels. The potential effect of $\mathrm{E}_{2}$ on the hepatic GHR signaling pathway can be mediated by $\mathrm{E}_{2}$-inducible sup- pressor of cytokine signaling (SOCS) proteins, which are described as negative regulators of the GHR signaling pathway (Adams, 1998; Davey et al., 1999; Hansen et al., 1999; Karlsson et al., 1999; Tollet-Egnell et al., 1999b; Morales et al., 2002; Du et al., 2003), or by a different hepatic expression of hepatic GHR (Colak et al., 2011). Therefore, the aim of the present study was to analyze blood concentrations of GH, IGF-I, and IGF-II and the hepatic GHR signaling pathway, particularly regarding hepatic GHR and SOCS expression, during the luteal phase and around ovulation in physiological estrus cycles of dairy heifers. We hypothesized that hepatic SOCS expression is maximally increased after ovulation and thereby after a long period of increased estradiol.

\section{MATERIALS AND METHODS}

\section{Animals}

Clinically healthy Holstein Friesian heifers $(\mathrm{n}=30)$, from a dairy herd in Ansager, Denmark, were purchased

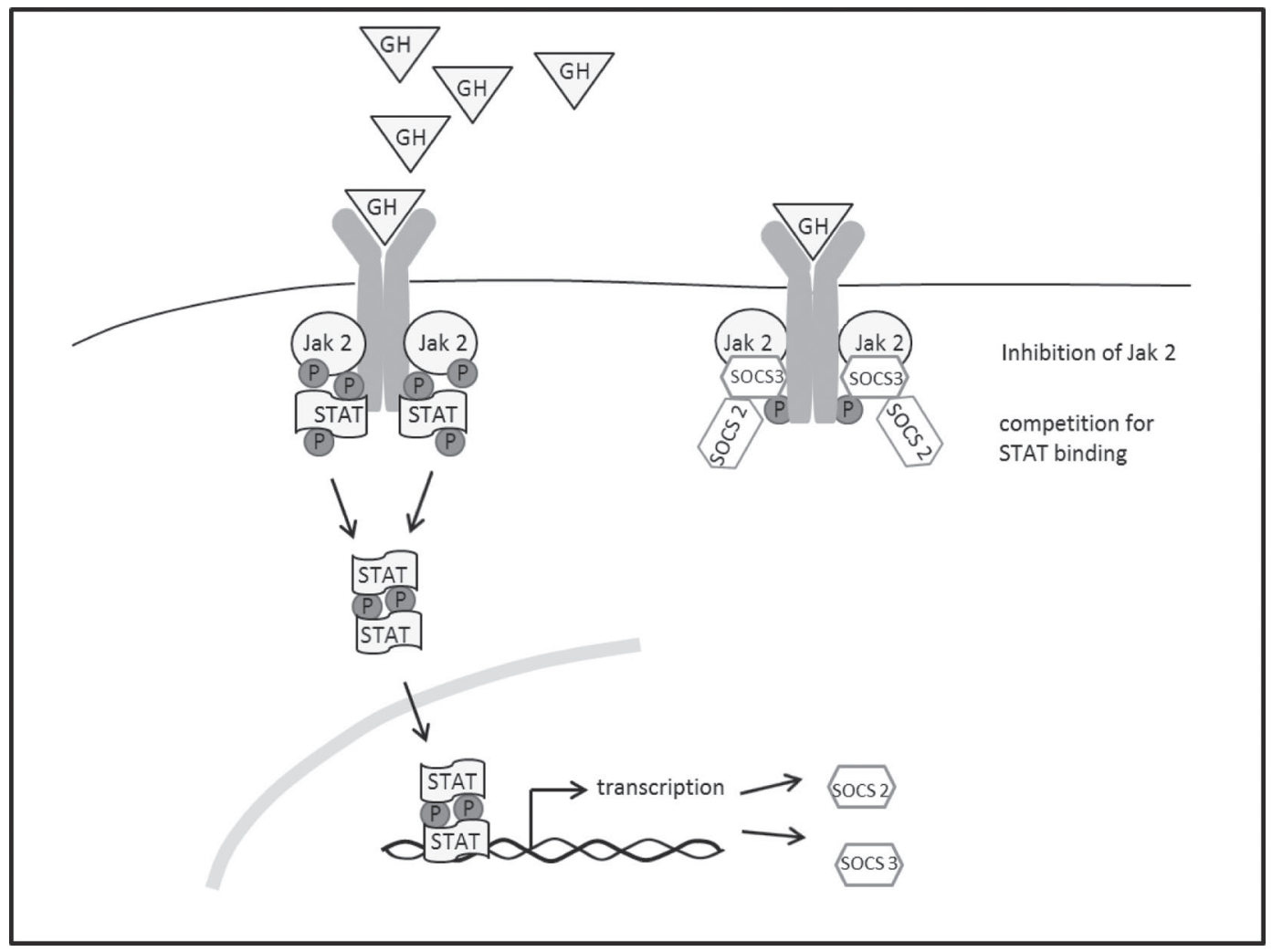

Figure 1. A schematic illustration of the Jak-Stat signal pathway and regulation by suppressors of cytokine signaling (SOCS2, SOCS3); growth hormone (GH) binds to the extracellular domain of the growth hormone receptor (GHR) dimer and auto-phosphorylates (P) 2 Janus kinase 2 proteins (JAK2) associated with the intracellular domain of this receptor. Thereby, tyrosine residues of the intracellular domain of the GHR are phosphorylated, which results in the formation of a binding site for signal transducers and the activator of transcription proteins (STAT) and its activation through phosphorylation. Two phosphorylated STAT monomers form a dimer, translocate into the cell nucleus, bind at specific GH-dependent DNA sequences, and indicate transcription (e.g., IGF-I, IGF-II). 
by Masterrind (Verden, Germany). After a clinical examination, the heifers (mean age of $13.8 \pm 1.0 \mathrm{mo}$ ) were maintained in the clinic for an adaptation period of 8 wk and the subsequent experiment. The heifers were placed in tiestalls on straw, fed hay twice daily, and had free access to fresh water and mineral licks (Deutsche Raiffeisen-Warenzentrale GmbH, Frankfurt, Germany). Before each experiment, each animal received a $\mathrm{Ru}-$ mifert bolus (Boehringer Ingelheim Vetmedica GmbH, Frankfurt, Germany) to ensure an optimal supply of cobalt, copper, and selenium. During the experiment, an ovarian ultrasound (Logiq Book XP and 10-MHz linear transducer probe, General Electric Medical Systems, Jiangsu, China) was performed daily to determine the day of ovulation (d 0 ) and the cycle stages. In total, 56 repeated physiological estrus cycles $(\mathrm{n}=56)$ of 30 heifers were used to obtain blood samples (between 0800 and $1000 \mathrm{~h}$ ) and liver biopsies during the luteal phase (CLP; $\mathrm{n}=56, \mathrm{~d} 12 \pm 1$ after ovulation) and around ovulation: directly before ovulation $(\mathbf{b O v} ; \mathrm{n}=$ 7) and after ovulation $(\mathbf{a O v} ; \mathrm{n}=49)$. The average time between these repeatedly supervised cycles was 79 $\pm 3 \mathrm{~d}$. Around ovulation, if estrus signs were observed and a follicle $>1.0 \mathrm{~cm}$ was detected by ultrasonography, ovarian ultrasound was performed twice daily (every 12 h) to precisely detect the time of ovulation. The study was performed in accordance with German legislation on animal welfare (Lower Saxony Federal State Office for Consumer Protection 279 and Food Safety).

\section{Blood Samples}

Blood samples were drawn from the coccygeal vein. For each animal, a serum tube and an EDTA tube (Sarstedt, Nümbrecht, Germany) were filled with $9 \mathrm{~mL}$ of blood, left at room temperature for approximately 2 $\mathrm{h}$, and centrifuged for $10 \mathrm{~min}$ at 1,500 $\times g(\mathrm{EBA} \mathrm{20}$, Hettich Zentrifugen, Tuttlingen, Germany). The serum and plasma were then transferred to a 2-mL Eppendorf tube (Eppendorf AG, Hamburg, Germany) and stored at $-20^{\circ} \mathrm{C}$ until further analysis.

\section{Liver Biopsies}

Biopsies of liver tissue were obtained before and after ovulation as well as during CLP. After fixation of the animal, an area of $15 \times 15 \mathrm{~cm}$ on the right side of the body, on an imaginary line from the tuber coxae to the cubital joint and within the 11th and 12th intercostal space, was soaped, shaved, washed, and degreased with $70 \%$ ethanol. Ultrasonography was performed to localize the optimal position and direction for the puncture (Power Vision 6000 and convex transducer probe, 3.75-MHz; Toshiba, Tokyo, Japan). The area was then disinfected with iodine solution (Vet-Sept, Albrecht GmbH, Aulendorf, Germany). After local subcutaneous and intramuscular anesthesia with $12 \mathrm{~mL}$ of Procasel $2 \%$ (Selectavet, Munich, Germany) and at a residence time of $10 \mathrm{~min}$, the skin was perforated by using a punctuation cannula (diameter $2.7 \mathrm{~mm}$; Hauptner Herberholz, Solingen, Germany), and 2 to 3 biopsies of liver tissue were obtained with a percutaneous needle biopsy system (Bard Magnum, Covington, GA). The liver biopsies were transferred into sterile Eppendorf cups, immediately frozen in liquid nitrogen, and stored at $-80^{\circ} \mathrm{C}$ until mRNA extraction. After drawing the liver biopsy, the perforation wound was swabbed with iodine solution and covered with Vet-Sept ointment (aniMedica, Senden-Bösensell, Germany).

\section{Endocrine Analyses}

Progesterone and 17 $\boldsymbol{\beta}$-Estradiol. To determine serum $\mathrm{P}_{4}$ concentrations, an automated competitive chemiluminescence immunoassay (LKPG1, Immulite 1000 System, Siemens Diagnostics, Los Angeles, CA) was used. The intraassay CV was 6.3 to $16 \%$ and the interassay CV was 5.8 to $16 \%$. The analytical sensitivity was $0.09 \mathrm{ng} / \mathrm{mL}$.

A previously described and validated RIA was used to determine the serum concentration of $\mathrm{E}_{2}$ (Rantala et al., 2014).

Growth Hormone. Plasma GH concentration was determined using an ELISA previously described by Roh et al. (1997) and Kawashima et al. (2007a) with modifications described by Piechotta et al. (2013). The plasma samples were diluted 1:1 in chicken serum (Sigma-Aldrich, St. Louis, MO). A microtiter plate (Thermo Fisher Scientific, Waltham, MA) coated with antibody against rabbit immunoglobulin (TUM School of Life Sciences, Weihenstephan, Germany) was incubated for $24 \mathrm{~h}$ at room temperature with an antibody against ovine $\mathrm{GH}[100 \mu \mathrm{L}, 1: 20$, rabbit antioGH-3, Lot\# AFP0802210Rb; A. F. Parlow, National Hormone and Peptide Program, National Institute of Diabetes and Digestive and Kidney Diseases (NIDDK), Torrance, CA]. After removal of antibody fluids and washing, either diluted GH standard $(15 \mu \mathrm{L} ; 0.78$ to $100 \mathrm{ng} / \mathrm{mL}$, NIDDK-bGH, AFP-10325C) or the plasma samples were transferred into the wells, and $1 \%$ chicken serum diluted in assay buffer was added. After incubation for $24 \mathrm{~h}$ at room temperature and washing, a biotin-labeled bovine GH was added to all wells and incubated for $3 \mathrm{~h}$ at room temperature followed by washing. Streptavidin-horseradish peroxidase (Sigma-Aldrich) and, after washing, the substrate tetramethylbenzidine (Sigma-Aldrich), were added. The reaction was stopped by adding $2 M$ sulfuric acid (Sigma-Aldrich). The opti- 
cal density was obtained at a wavelength of $450 \mathrm{~nm}$. Then, concentrations of GH were calculated using Magellan software with the cubic spline modus (Magellan 3.11, Magellan, Dortmund, Germany). This method has been previously validated for use in bovine samples (Piechotta et al., 2013). The intra- and interassay CV were 9.8 and $12.6 \%$, respectively. The lowest detection limit for $\mathrm{GH}$ was $2.0 \mathrm{ng} / \mathrm{mL}$.

$\boldsymbol{I G F - I}$ and $\boldsymbol{I} \boldsymbol{G F}-\boldsymbol{I I}$ The total serum IGF-I concentration was determined using a commercial RIA according to the manufacturer's instructions (IGF-I IRMA A15729, Beckman Coulter, Brea, CA). This method is based on the "sandwich" principle, and the detection antibodies were mouse monoclonal antibodies against 2 epitopes of IGF-I. The intraassay CV was $5.1 \%$, the interassay CV was $9.3 \%$, and the lowest detection limit for IGF-I was $30 \mathrm{ng} / \mathrm{mL}$.

To determine the serum IGF-II concentration, a commercially available IGF-II ELISA (Mediagnost, Reutlingen, Germany) test was used following the manufacturer's instructions. This sandwich-based ELISA was previously validated for bovine serum to measure the IGF-II concentration in the serum samples. Bovine serum was diluted 1:5 in sample buffer, and the intraand interassay CV were determined by measuring 20 dilutions of this bovine serum within or between 10 test runs. The intra- and interassay CV were 6.6 and $7.2 \%$, respectively, and the lowest detection limit of the ELISA was $0.45 \mathrm{ng} / \mathrm{mL}$.

\section{RNA Isolation and Quantitative Real-Time Reverse Transcription-PCR}

The relative abundances of ER $, G H R, J A K 2$, STAT5B, SOCS2, SOCS3, IGF-I, and IGF-II mRNA in the liver biopsies were detected using quantitative realtime reverse transcription-PCR (RT-qPCR). Initially, the total RNA extraction was performed using RNeasy Mini Kits for animal tissue and cells according to the manufacturer's instructions (Qiagen, Mississauga, ON, Canada). After degeneration of the cell structure, the lysate was pipetted into an Eppendorf tube and further processed in an automated system according to the manufacturer's instructions (QIAcube, Qiagen). To assess the quality and quantity of the extracted RNA, relative integrity was determined using the RNA 6000 Nano Assay Kit and Agilent 2100 Bioanalyzer (Agilent Technologies, Böblingen, Germany). All samples with a relative integrity number $>7.5$ were applied to cDNA synthesis by reverse transcription as previously described (Piechotta et al., 2013). Finally, to transcribe RNA into cDNA, the BioRad Real Time System CFX96 1000 Touch (BioRad, Munich, Germany) was used according to the manufacturer's instructions. A PCR reaction mix, which contained $10 \mu \mathrm{L}$ of Mesa Green PCR MasterMix Plus for SYBR Assay (Eurogentec, Cologne, Germany) and $0.2 \mu M$ concentrations of each primer (Eurofins MWG Operon, Ebersberg, Germany) for the genes of interest, was used. The primers were either previously described or constructed using http:// biotools.umassmed.edu/bioapps/primer3_www.cgi; the respective sequences and accession numbers are shown in Table 1 . The PCR cycler was programmed as follows: RNA denaturation at $95^{\circ} \mathrm{C}$ for $15 \mathrm{~min}$ and 43 cycles of $95^{\circ} \mathrm{C}$ for $15 \mathrm{~s}, 60^{\circ} \mathrm{C}$ for $30 \mathrm{~s}$, and $72^{\circ} \mathrm{C}$ for $30 \mathrm{~s}$ for amplification. The fragments were visualized using SYBR Green (BioRad). A subsequent melting curve was generated to verify the PCR fragments and was initiated at $55^{\circ} \mathrm{C}$ to a final temperature of $95^{\circ} \mathrm{C}$ with an increase of $0.5^{\circ} \mathrm{C}$ every $10 \mathrm{~s}$. Finally, the relative abundances of ERQ, GHR, JAK2, STAT5B, SOCS2, $S O C S 3, I G F-I$, and IGF-II mRNA in the liver biopsies was calculated using Microsoft Excel 2010 (Microsoft Corp., Redmond, WA) relative to the housekeeping genes, ribosomal protein S9 (RPS9) and GAPDH, which did not differ between cows in the luteal phase or follicular phase. The $\Delta \mathrm{Ct}$ (delta cycle threshold) method was used to calculate the relative abundance of mRNA in the liver biopsies. The mean value of the Ctmerit of a specific gene was subtracted from the mean value of the 2 housekeeping genes ( $R P S 9$ and GAPDH), and calculated by the formula $2^{-\Delta \mathrm{Ct}}$ multiplied by 100 .

\section{Statistics}

For statistical analyses, SAS (version 9.2., SAS Institute Inc., Cary, NC) was used. The data were tested for normal distribution using the Kolmogorov-Smirnov test ( $\mathrm{n}>90$; PROC UNIVARIATE normal plot). Data (ER $\alpha$ mRNA, GHR mRNA, IGF-II blood concentration) that did not deviate significantly from a normal distribution were presented as means \pm standard error (SE). All other data obtained that were not normally distributed were mathematically transformed to achieve normal distribution. Thus, before parametric statistical methods were applied, the following transformations were used: IGF-I, JAK2, SOCS2, and SOCS3 mRNA and IGF-I concentrations were transformed using the exponent $1 / 4$ transformation $\left[(\mathrm{X})^{1 / 4}\right]$ and STAT5B mRNA and IGF-II mRNA were transformed using the exponent $1 / 3$ transformation $\left[(\mathrm{X})^{1 / 3}\right]$ before parametric statistical methods were applied. Significant differences were identified using repeated-measures ANOVA, whereas fixed effects were assessed using PROC MIXED and residual (restricted) maximum likelihood (REML). The main effects - phases of estrus cycle and number of estrus cycles - and interactions were defined. Additionally, the effects of estrus cycle 
Table 1. Quantitative real-time PCR primers for genes of interest in the liver biopsies obtained before ovulation, after ovulation, and during the luteal phase

\begin{tabular}{|c|c|c|c|}
\hline Gene $^{1}$ & Primer & Primer sequence $\left(5^{\prime} \rightarrow 3^{\prime}\right)$ & $\begin{array}{l}\text { Accession } \\
\text { number/reference }\end{array}$ \\
\hline$G A P D H$ & $\begin{array}{l}\text { Forward } \\
\text { Reverse }\end{array}$ & $\begin{array}{l}\text { caa cat caa gtg ggg tga tg } \\
\text { ggc att gct gac aat ctt ga }\end{array}$ & NM_001034034.1 \\
\hline$R P S 9$ & $\begin{array}{l}\text { Forward } \\
\text { Reverse }\end{array}$ & $\begin{array}{l}\text { gat tac atc ctg ggc ctg aa } \\
\text { cag gga gaa gtc gat gtg ct }\end{array}$ & NM_001101152 \\
\hline$E R \alpha$ & $\begin{array}{l}\text { Forward } \\
\text { Reverse }\end{array}$ & $\begin{array}{l}\text { gac cga aga gga ggg aga at } \\
\text { cac cgg gct gtt ctt ctt ag }\end{array}$ & AY538775.1 \\
\hline GHR1A & $\begin{array}{l}\text { Forward } \\
\text { Reverse }\end{array}$ & $\begin{array}{l}\text { cgt ctc tgc tgg tga aaa ca } \\
\text { gga tgt cgg cat gaa tct ct }\end{array}$ & NM_176608.1 \\
\hline Jak2 & $\begin{array}{l}\text { Forward } \\
\text { Reverse }\end{array}$ & $\begin{array}{l}\text { ttg gca atg aca aac aag ga } \\
\text { atc tca tct ggg cat cca tc }\end{array}$ & Cummins et al., 2012 \\
\hline STAT5B & $\begin{array}{l}\text { Forward } \\
\text { Reverse }\end{array}$ & $\begin{array}{l}\text { tgc atc cgc cat att ctg ta } \\
\text { agt } \operatorname{cgc} \text { agc tcc tca aat gt }\end{array}$ & Cummins et al., 2012 \\
\hline SOCS2 & $\begin{array}{l}\text { Forward } \\
\text { Reverse }\end{array}$ & $\begin{array}{l}\text { gtg tgg caa ggt agc tag gg } \\
\text { tac cag tgc tgg gac ctt tc }\end{array}$ & NM_177523.2 \\
\hline SOCS3 & $\begin{array}{l}\text { Forward } \\
\text { Reverse }\end{array}$ & $\begin{array}{l}\text { cca gcc tgc gcc tca aga cc } \\
\text { aaa gtg gcg ctg gtc cga gc }\end{array}$ & Cummins et al., 2012 \\
\hline$I G F-I$ & $\begin{array}{l}\text { Forward } \\
\text { Reverse }\end{array}$ & $\begin{array}{l}\text { ttg cac ttc aga agc aat gg } \\
\text { act gga gag cat cca cca ac }\end{array}$ & NM_001077828.1 \\
\hline$I G F-I I$ & $\begin{array}{l}\text { Forward } \\
\text { Reverse }\end{array}$ & $\begin{array}{l}\text { gtg gtt cca tct ttc cga ga } \\
\text { aac cgt tcc tca tct tgc ac }\end{array}$ & NM_174087.3 \\
\hline
\end{tabular}

phases on $\mathrm{P}_{4}$ and $\mathrm{E}_{2}$ concentrations were tested according to Littell et al. $(1998,2000)$. The Bayesian-Schwarz criterion and Akaike information criterion were used to determine the optimal covariance structure matrix $\left(\mathrm{P}_{4}\right.$ and $\mathrm{E}_{2}=$ first-order auto-regressive) for the statistical model (Littell et al., 1998, 2000). The effects of the cycle phases CLP, bOv, and aOv on concentrations of $\mathrm{P}_{4}$ and $\mathrm{GH}$, which were not normally distributed, were calculated by using a nonparametric ANOVA with the Kruskal-Wallis test (PROC NPAR1WAY). To detect statistical differences between variables (independent: $1=\mathrm{bOv}, 2=\mathrm{aOv}$, and $3=\mathrm{CLP}$ ) and dependent variables (blood hormone concentrations and mRNA data), a parametric ANOVA was performed (Proc GLM and PDIFF). The relationships between and within parameters were evaluated using the Spearman correlation (PROC CORR Spearman; SAS Institute Inc.).

\section{RESULTS}

\section{Animals}

The mean observed length of an estrus cycle was 20 \pm 2 d. During the luteal phase, the diameter of the corpus luteum was $2.2 \pm 0.4 \mathrm{~cm}$. The mean diameter of the Graafian follicle before ovulation was $1.4 \pm 0.2 \mathrm{~cm}$.

\section{Blood Parameters}

Sexual Steroid Hormones. The concentration of $\mathrm{P}_{4}$ was higher during CLP compared with bOv and $\mathrm{aOv}$. The concentration of $\mathrm{E}_{2}$ was lower in CLP compared with bOv but comparable to that during aOv (Table 2).

$\boldsymbol{G H}, \boldsymbol{I G F - I , ~ a n d ~ I G F - I I . ~ T h e ~ p l a s m a ~ c o n c e n t r a - ~}$ tion of GH was lower during CLP compared with bOv

Table 2. The mean and standard error of hormone concentration in blood samples obtained before ovulation, after ovulation, and during the luteal phase

\begin{tabular}{|c|c|c|c|}
\hline Item & \multicolumn{2}{|c|}{ Ovulation } & Luteal phase \\
\hline $\begin{array}{l}\text { Progesterone }(\mathrm{ng} / \mathrm{mL}) \\
(\text { IGF-I })^{1 / 4}(\mathrm{ng} / \mathrm{mL})^{1} \\
\text { IGF-II }(\mathrm{ng} / \mathrm{mL}) \\
\text { Growth hormone }(\mathrm{ng} / \mathrm{mL}) \\
\text { 17ß-Estradiol }(\mathrm{pg} / \mathrm{mL})\end{array}$ & $\begin{aligned} 0.19 & \pm 0.06^{\mathrm{b}} \\
4.22 & \pm 0.10^{\mathrm{a}}[323.40 \pm 29.47] \\
52.39 & \pm 3.09^{\mathrm{ab}} \\
23.34 & \pm 10.08^{\mathrm{a}} \\
11.5 & \pm 4.3^{\mathrm{a}}\end{aligned}$ & $\begin{aligned} 0.18 & \pm 0.02^{\mathrm{b}} \\
4.26 & \pm 0.03^{\mathrm{a}}[334.33 \pm 10.52] \\
48.78 & \pm 1.16^{\mathrm{b}} \\
10.22 & \pm 1.22^{\mathrm{b}} \\
7.4 & \pm 2.3^{\mathrm{b}}\end{aligned}$ & $\begin{aligned} 5.93 & \pm 0.21^{\mathrm{a}} \\
4 & \pm 0.03^{\mathrm{b}}[260.11 \pm 8] \\
56.30 & \pm 1.25^{\mathrm{a}} \\
5.78 & \pm 0.66^{\mathrm{c}} \\
7.3 & \pm 2.9^{\mathrm{b}}\end{aligned}$ \\
\hline
\end{tabular}

${ }^{\mathrm{a}-\mathrm{c}}$ Means within a row with different superscripts differ $(P<0.05)$.

${ }^{1}(\mathrm{IGFI})^{1 / 4}=$ exponent $1 / 4$ power-transformed insulin-like growth factor-I. Values in brackets not transformed. 
Table 3. The mean $( \pm \mathrm{SE})$ of mRNA relative abundance for genes of interest during the luteal and follicular phases, before and after ovulation using ribosomal protein S9 (RPS9) and GAPDH as housekeeping genes

\begin{tabular}{|c|c|c|c|}
\hline \multirow[b]{2}{*}{$\mathrm{mRNA}^{1}$} & \multicolumn{2}{|c|}{ Ovulation } & \multirow[b]{2}{*}{ Luteal phase } \\
\hline & Before ovulation & After ovulation & \\
\hline$E R \alpha$ & $11.50 \pm 1.52$ & $9.55 \pm 0.61$ & $9.86 \pm 0.58$ \\
\hline GHR & $98.77 \pm 17.31^{\mathrm{a}}$ & $65.76 \pm 3.86^{\mathrm{b}}$ & $61.55 \pm 4.10^{\mathrm{b}}$ \\
\hline$I G F-I$ & $12.33 \pm 2.96$ & $9.67 \pm 0.89$ & $9.23 \pm 0.96$ \\
\hline$J A K^{2}$ & $3.21 \pm 0.55$ & $2.56 \pm 0.19$ & $2.64 \pm 0.21$ \\
\hline$(S O C S 2)^{1 / 4}$ & $2.21 \pm 0.10^{\mathrm{a}}[25.65 \pm 4.86]$ & $1.85 \pm 0.041^{\mathrm{b}}[13.45 \pm 1.19]$ & $1.8 \pm 0.04^{\mathrm{b}}[12.49 \pm 1.29]$ \\
\hline $\mathrm{SOCS}_{3}$ & $8.85 \pm 0.78$ & $7.96 \pm 0.62$ & $8.24 \pm 0.62$ \\
\hline STAT5B & $10.03 \pm 1.69$ & $8.88 \pm 0.63$ & $9.08 \pm 0.73$ \\
\hline$I G F-I I$ & $0.58 \pm 0.07$ & $0.51 \pm 0.04$ & $0.56 \pm 0.04$ \\
\hline
\end{tabular}

a,b Means within a row with different superscripts differ $(P<0.05)$.

${ }^{1} E R \alpha=17 \beta$-estradiol receptor $\alpha ; G H R=$ growth hormone receptor; IGF-I = insulin-like growth factor-I; Jak2 $=$ Janus kinase- $2 ;(S O C S 2)^{1 / 4}=$ exponent $1 / 4$ power-transformed suppressor of cytokine signaling-2; SOCS3 = suppressor of cytokine signaling-3; STAT5B = signal transducer and activator of transcription 5B; IGF-II= insulin-like growth factor-II. For $(S O C S 2)^{1 / 4}$, values in brackets were not transformed.

and $\mathrm{aOv}$ (Table 2), and bOv and aOv GH concentrations were comparable. Figure 2 shows the GH blood concentration as rank-blot diagrams and clearly indicates a higher $\mathrm{GH}$ concentration bOv compared with aOv and CLP $(P<0.05)$. Moreover, GH was significantly higher bOv compared with aOv $(P<0.05)$. The serum concentration of IGF-I was lower during the CLP compared with $\mathrm{bOv}$ and $\mathrm{aOv}$, whereas the IGF-I concentration was comparable in bOv and aOv (Table 2).

In contrast, the serum concentration of IGF-II was lower aOv than bOv or during CLP $(P<0.05)$. No difference was observed between bOv and aOv in regard to IGF-II levels (Table 2).

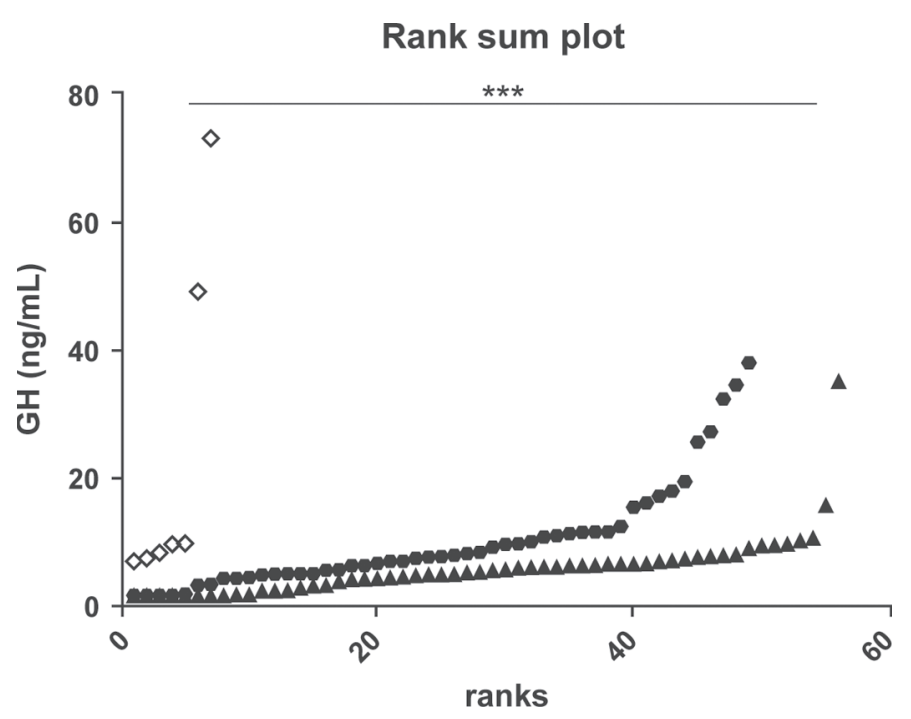

Figure 2. Rank-sum plot of growth hormone $(\mathrm{GH})$ concentrations before ovulation (bOv; $\diamond)$, after ovulation (aOV; $\bullet$ ) and during the luteal phase (CLP; $\mathbf{\Delta})$, plotted by assigning to each GH concentration observed in a given population the fraction of the population according to Xu et al. (2011).

\section{RT-qPCR Analyses of Liver Biopsies}

The expression of $G H R$ was significantly higher bOv than aOv $(P<0.01)$ and during the CLP $(P<0.01)$, whereas expression of $G H R$ aOv was comparable to that during the CLP. The relative abundance of the SOCS2 mRNA was significantly higher bOv than aOv $(P<0.01)$. The expression of SOCS2 was significantly higher bOv than during the CLP $(P<0.01)$, whereas SOCS2 expression aOv was comparable to the CLP. The relative abundance of ER $\alpha, J A K 2, S T A T 5 B$, SOCS3, IGF-I, and IGF-II mRNA were comparable during CLP, bOv, and aOv (Table 3). The expression of SOCS2 mRNA was significantly correlated with expression of ER $\alpha$ and STAT5B (Table 4). However, no highly significant correlations were found between hepatic mRNA expression and blood parameters in the present study (Table 4).

\section{DISCUSSION}

The aim of the study was to analyze the association between different endogenous $\mathrm{P}_{4}$ and $\mathrm{E}_{2}$ concentrations throughout a physiological cycle on blood concentrations of GH, IGF-I, and IGF-II, and the hepatic GHR signaling pathway, particularly regarding the expression of SOCS mRNA, a regulator of the Jak-Stat pathway (Du et al., 2003; Flores-Morales et al., 2006; Rico-Bautista et al., 2006) in dairy heifers. Because it was hypothesized, based on a previous study in dairy cows in late pregnancy (Winkelman et al., 2008), that SOCS2 expression increases during a period of high estradiol, we obtained blood samples and liver biopsies in the luteal phase and after a prolonged phase of estradiol (after ovulation). To ensure that SOCS2 expression was highest aOv, some samples were also taken bOv, were the peak of estradiol was expected. Therefore, the 


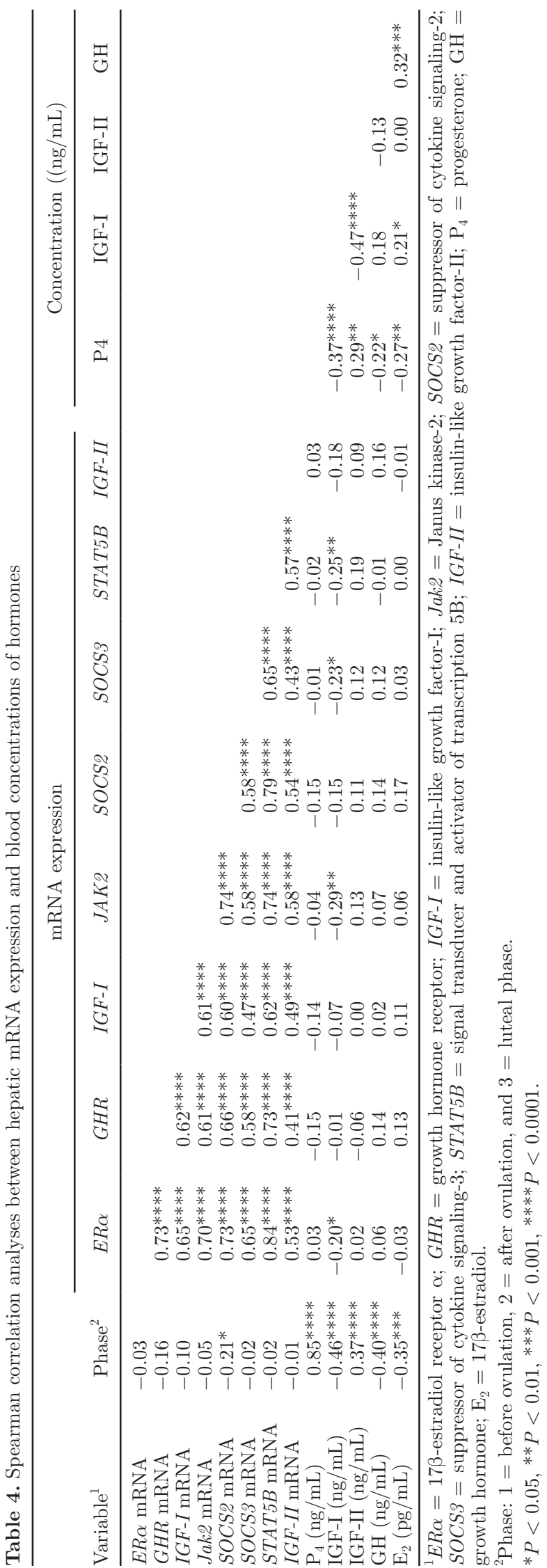

cows were monitored for a follicle $>1 \mathrm{~cm}$ and, if the follicle subsequently disappeared, a blood sample and a liver biopsy were taken.

The results clearly indicate that blood concentrations of GH increased during ovulation, and were highest bOv. The GH concentrations decreased already aOv, but were still higher aOv than during CLP. This finding was similar to results of previous studies in sheep (Dutour et al., 1997) and goats (Landefeld and Suttie, 1989; Yonezawa et al., 2005), and it indicates an influence of $E_{2}$ on pituitary $\mathrm{GH}$ release. It was also shown experimentally that $\mathrm{E}_{2}$ stimulates pituitary $\mathrm{GH}$ release and hepatic IGF-I production after injection into ovariectomized cattle (Colak et al., 2011). Kawashima et al. (2007b) and Alvarez et al. (2000) did not detect changes in GH blood concentrations during the physiological estrus cycle in dairy cows, in contrast to the results of the present study, in which GH concentration was higher during estrus. Alvarez et al. (2000), however, took blood samples on d 2 and 14 of the cycle, and therefore $\mathrm{E}_{2}$ concentrations might be lower than in the present study. This difference in study design might explain the differences between the studies. Notably, the blood samples in the present study were drawn after ovulation (d 0), which was carefully detected by a daily ultrasound of the ovaries, which is in contrast to other studies, such as that of Kawashima et al. (2007b), who only observed an increase in IGF-I blood concentrations. Moreover, GH has a pulsatile release (Mondal et al., 2005), and daily blood sampling is not a good technique to interpret the GH release; however, in the present study, a rank-sum plot was calculated as previously described by Xu et al. (2011), which allowed interpretation of daily measured GH values as the sum of values from one study group. This rank-sum plot evaluation underpins the result that $\mathrm{GH}$ was higher bOv than aOv and during CLP.

Increased IGF-I blood concentrations during estrus were shown by Kawashima et al. (2007b) in cattle, Yonezawa et al. (2005) in goats, and Spicer et al. (1991) in sheep, but were not detected in Alvarez et al. (2000) in different beef cattle breeds. However, higher IGF-I concentrations during estrus and $12 \mathrm{~h}$ after estrus can be confirmed by data from the present study in dairy heifers. Notably, in contrast to IGF-I levels, IGF-II were lower aOv compared with CLP. These data might indicate that the IGF-I and IGF-II levels were regulated reciprocally, presumably by different regulation pathways. This assumption is substantiated by the fact that the IGF-I and IGF-II blood concentrations were significantly negatively correlated. A study by Nikolić et al. (2001) in beef cattle also showed a reciprocal relationship between IGF-I and IGF-II. Notably, Hua et al. (1995) demonstrated a decrease in IGF-II blood 
concentrations after GH injection in sheep. However, the source of IGF-II in the blood in the present study was not obvious because hepatic mRNA production of $I G F-I I$ was comparable between bOv, aOv, and CLP, and we can only speculate about the pathways involved in the IGF-II decrease with high $\mathrm{E}_{2}$ levels.

The increased IGF-I blood concentration around ovulation and the higher IGF-I levels bOv than aOv could be caused either by central regulation via an increased GH release though estradiol or by changes in the hepatic GH signaling pathway, also mediated by estradiol.

In the present study, the expression of the main components of the hepatic GH signaling pathway $(E R \alpha$, GHR, JAK2, STAT5B, SOCS2, SOCS3, IGF-I, and $I G F-I I)$ was measured by RT-qPCR, and cycle stages with different sexual steroid hormone concentrations may have directly affected the hepatic GHR signaling pathway. Hepatic GHR expression increased immediately before ovulation, when the $\mathrm{E}_{2}$ blood concentration peaked. Colak et al. (2011) also described an increase in hepatic $G H R$ expression after an $\mathrm{E}_{2}$ injection in ovariectomized cattle parallel to increased $\mathrm{GH}$ pulsatility. However, from that data and the data of the present study, it is unclear whether the effect of estradiol on hepatic GHR was directed only by higher pituitary GH release or whether estradiol may also have an effect at the hepatic level. Jiang et al. (2007) treated cattle using a slow-release formula of GH and described an increase in GHR and IGF-I expression 1 wk after injection. Those authors concluded that GH stimulates GHR expression by the binding of STAT5 to the promoter of GHR; however, in the present study, the mRNA expression of STAT5 was comparable around ovulation and CLP, and binding of STAT5 to the GHR promoter was not tested. Further studies are necessary to clarify which mechanism enhances $G H R$ expression and its physiological role. Contreras and Talamantes (1999) observed that the combination of $\mathrm{E}_{2}$ and $\mathrm{GH}$ upregulated cellular concentrations of GHR 2- to 3-fold in primary mouse hepatocytes, whereas treatment with $\mathrm{GH}$ or $\mathrm{E}_{2}$ alone did not affect the cellular concentrations of GHR. These data may also support the hypothesis that not only is pituitary release of GH higher, but also hepatic GHR expression is upregulated during estrus (before ovulation) in dairy heifers. A similar assumption was made previously; Wathes et al. (2011) concluded that it seems likely that both $\mathrm{E}_{2}$ and $\mathrm{GH}$ are involved in regulating endometrial IGF-I synthesis in the postpartum cow (Wathes et al., 2011).

A predominantly inhibiting effect on the GH signaling pathway of SOCS proteins has been observed in humans, rodents, and cell culture studies (Adams, 1998; Davey et al., 1999; Hansen et al., 1999; Karls- son et al., 1999; Tollet-Egnell et al., 1999; Morales et al., 2002; Du et al., 2003). In the present study of dairy heifers, an increase in hepatic SOCS2 mRNA expression was observed directly bOv compared with liver tissue obtained $\mathrm{aOv}$ and the CLP. It could be hypothesized that endogenous $\mathrm{E}_{2}$ has a contemporary stimulating effect on hepatic SOCS2 expression before ovulation. If $\mathrm{GH}$ binds to GHR, GHR expression increases, but SOCS2 expression increases to attenuate the signal. This could be the underlying mechanism for why $I G F-I$ expression in the bovine liver was not increased during estrus. The increased SOCS2 expression may have previously inhibited IGF-I mRNA expression around ovulation; therefore, no significant difference to CLP could be detected by RT-qPCR. However, IGF-I blood concentration remained increased, and we can speculate that this is because of a prolonged half-life through the binding of IGF-I to IGF binding proteins. As binding proteins were not measured in the present study, we cannot substantiate this speculation and it should be addressed in further studies. Moreover, only mRNA data were measured in the present study; detection of phosphorylation status by Western blot could substantiate the hypothesis and should be addressed in follow-up experiments. Studies in rodents and cell cultures have shown increased SOCS2 transcription via STAT5 induction by treatment with GH (Adams, 1998; Davey et al., 1999; Tollet-Egnell et al., 1999; Thangavel and Shapiro, 2007). Moreover, a direct effect of $\mathrm{E}_{2}$ via $\mathrm{ER} \alpha$ on the hepatic transcription of SOCS2 appears plausible. This idea might be supported by data from the study of Leong et al. (2004), who described an influence of $\mathrm{E}_{2}$ in ovariectomized mice with or without $\mathrm{ER} \alpha$. After a 3-wk treatment of mice with $\mathrm{E}_{2}$, SOCS2 and SOCS3 expression increased only in mice expressing hepatic ER $\alpha$.

Notably, in the present physiological evaluation, increased SOCS2 expression during estrus was detected simultaneously to the increase in $\mathrm{E}_{2}$ in the blood before ovulation. This contemporary effect of $\mathrm{E}_{2}$ on SOCS2 expression in heifers and the increased GHR expression before ovulation provides more detailed, basic knowledge regarding the regulation of the somatotropic axis. However, detailed in vitro studies are necessary to clarify the exact mechanism of SOCS2 feedback on GHR signaling during estrus in heifers.

\section{ACKNOWLEDGMENTS}

We thank Martina Baumgarten and Angela Jordan (University of Veterinary Medicine, Clinic for Cattle, Endocrinology, Hanover, Germany) for technical help with endocrine analyses. Moreover, we acknowledge the support of Zoetis (Florham Park, NJ) and of the iPUD 
project under an EMIDA ERA-Net award to Martin Sheldon (Swansea University, UK).

\section{REFERENCES}

Adams, T. E. 1998. Growth hormone preferentially induces the rapid, transient expression of SOCS-3, a novel inhibitor of cytokine receptor signaling. J. Biol. Chem. 273:1285-1287.

Alvarez, P., L. J. Spicer, C. C. Chase, M. E. Payton, T. D. Hamilton, R. E. Stewart, A. C. Hammond, T. A. Olson, and R. P. Wettemann. 2000. Ovarian and endocrine characteristics during an estrous cycle in Angus, Brahman, and Senepol cows in a subtropical environment. J. Anim. Sci. 78:1291-1302.

Armstrong, D. G., J. G. Gong, and R. Webb. 2003. Interactions between nutrition and ovarian activity in cattle: Physiological, cellular and molecular mechanisms. Reprod. Suppl. 61:403-414.

Baumann, G. 2001. Growth hormone binding protein 2001. J. Pediatr. Endocrinol. Metab. 14:355-375.

Bichell, D. P., K. Kikuchi, and P. Rotwein. 1992. Growth hormone rapidly activates insulin-like growth factor I gene transcription in vivo. Mol. Endocrinol. 6:1899-1908.

Breier, B. H. 1999. Regulation of protein and energy metabolism by the somatotropic axis. Domest. Anim. Endocrinol. 17:209-218.

Colak, M., T. Shimizu, N. Matsunaga, C. Murayama, S. Nagashima, M. Kataoka, C. Kawashima, M. Matsui, H. A. van Dorland, R. M. Bruckmaier, and A. Miyamoto. 2011. Oestradiol enhances plasma growth hormone and insulin-like growth factor-I concentrations and increased the expression of their receptors mRNAs in the liver of ovariectomized cows. Reprod. Domest. Anim. 46:854-861.

Contreras, B., and F. Talamantes. 1999. Growth hormone (GH) and 17beta-estradiol regulation of the expression of mouse GH receptor and GH-binding protein in cultured mouse hepatocytes. Endocrinology 140:4725-4731.

Cummins, S. B., S. M. Waters, A. C. O. Evans, P. Lonergan, and S. T. Butler. 2012. Genetic merit for fertility traits in Holstein cows: III. Hepatic expression of somatotropic axis genes during pregnancy and lactation. J. Dairy Sci. 95:3711-3721.

Davey, H. W., M. J. McLachlan, R. J. Wilkins, D. J. Hilton, and T. E. Adams. 1999. STAT5b mediates the GH-induced expression of SOCS-2 and SOCS-3 mRNA in the liver. Mol. Cell. Endocrinol. 158:111-116.

Du, L., G. P. Frick, L. R. Tai, A. Yoshimura, and H. M. Goodman. 2003. Interaction of the growth hormone receptor with cytokineinduced Src homology domain 2 protein in rat adipocytes. Endocrinology 144:868-876.

Dutour, A., N. Briard, V. Guillaume, E. Magnan, M. Cataldi, N. Sauze, and C. Oliver. 1997. Another view of GH neuroregulation: Lessons from the sheep. Eur. J. Endocrinol. 136:553-565.

Flores-Morales, A., C. J. Greenhalgh, G. Norstedt, and E. Rico-Bautista. 2006. Negative regulation of growth hormone receptor signaling. Mol. Endocrinol. 20:241-253.

Gourmelen, M., Y. Le Bouc, F. Girard, and M. Binoux. 1984. Serum levels of insulin-like growth factor (IGF) and IGF binding protein in constitutionally tall children and adolescents. J. Clin. Endocrinol. Metab. 59:1197-1203.

Grimberg, A., and P. Cohen. 2000. Role of insulin-like growth factors and their binding proteins in growth control and carcinogenesis. J. Cell. Physiol. 183:1-9.

Hansen, J. A., K. Lindberg, D. J. Hilton, J. H. Nielsen, and N. Billestrup. 1999. Mechanism of inhibition of growth hormone receptor signaling by suppressor of cytokine signaling proteins. Mol. Endocrinol. 13:1832-1843.

Herrington, J., and C. Carter-Su. 2001. Signaling pathways activated by the growth hormone receptor. Trends Endocrinol. Metab. 12:252-257.

Hua, K. M., S. C. Hodgkinson, and J. J. Bass. 1995. Differential regulation of plasma levels of insulin-like growth factors-I and -II by nutrition, age and growth hormone treatment in sheep. J. Endocrinol. 147:507-516.
Jiang, H., Y. Wang, M. Wu, Z. Gu, S. J. Frank, and R. Torres-Diaz. 2007. Growth hormone stimulates hepatic expression of bovine growth hormone receptor messenger ribonucleic acid through signal transducer and activator of transcription 5 activation of a major growth hormone receptor gene promoter. Endocrinology 148:3307-3315.

Karlsson, H., J. A. Gustafsson, and A. Mode. 1999. Cis desensitizes GH induced Stat5 signaling in rat liver cells. Mol. Cell. Endocrinol. 154:37-43.

Kawashima, C., S. Fukihara, M. Maeda, E. Kaneko, C. A. Montoya, M. Matsui, T. Shimizu, N. Matsunaga, K. Kida, Y.-I. Miyake, D. Schams, and A. Miyamoto. 2007a. Relationship between metabolic hormones and ovulation of dominant follicle during the first follicular wave post-partum in high-producing dairy cows. Reproduction 133:155-163.

Kawashima, C., K. Kida, K.-G. Hayashi, C. Amaya Montoya, E. Kaneko, N. Matsunaga, T. Shimizu, M. Matsui, Y.-I. Miyake, D. Schams, and A. Miyamoto. 2007b. Changes in plasma metabolic hormone concentrations during the ovarian cycles of Japanese Black and Holstein cattle. J. Reprod. Dev. 53:247-254.

Landefeld, T. D., and J. M. Suttie. 1989. Changes in messenger ribonucleic acid concentrations and plasma levels of growth hormone during the ovine estrous cycle and in response to exogenous estradiol. Endocrinology 125:1474-1478.

Lassarre, C., S. Hardouin, F. Daffos, F. Forestier, F. Frankenne, and M. Binoux. 1991. Serum insulin-like growth factors and insulin-like growth factor binding proteins in the human fetus. Relationships with growth in normal subjects and in subjects with intrauterine growth retardation. Pediatr. Res. 29:219-225.

Leong, G. M., S. Moverare, J. Brce, N. Doyle, K. Sjögren, K. Dahlman-Wright, J.-A. Gustafsson, K. K. Y. Ho, C. Ohlsson, and K.-C. Leung. 2004. Estrogen up-regulates hepatic expression of suppressors of cytokine signaling-2 and -3 in vivo and in vitro. Endocrinology $145: 5525-5531$.

Littell, R. C., P. R. Henry, and C. B. Ammerman. 1998. Statistical analysis of repeated measures data using SAS procedures. J. Anim. Sci. 76:1216-1231.

Littell, R. C., J. Pendergast, and R. Natarajan. 2000. Modelling covariance structure in the analysis of repeated measures data. Stat. Med. 19:1793-1819.

Lucy, M. C., H. Jiang, and Y. Kobayashi. 2001. Changes in the somatotrophic axis associated with the initiation of lactation. J. Dairy Sci. 84:113-119.

Mondal, M., C. Rajkhowa, and B. S. Prakash. 2005. Diurnal changes in blood metabolites and their relation to plasma growth hormone and time of feeding in mithun heifers (Bos frontalis). Chronobiol. Int. 22:807-816.

Morales, O., M. H. Faulds, U. J. Lindgren, and L.-A. Haldosén. 2002. 1Alpha,25-dihydroxyvitamin D3 inhibits GH-induced expression of SOCS-3 and CIS and prolongs growth hormone signaling via the Janus kinase (JAK2)/signal transducers and activators of transcription (STAT5) system in osteoblast-like cells. J. Biol. Chem. 277:34879-34884.

Moses, A. C., S. P. Nissley, P. A. Short, M. M. Rechler, R. M. White, A. B. Knight, and O. Z. Higatl. 1980. Increased levels of multiplication-stimulating activity, an insulin-like growth factor, in fetal rat serum. Proc. Natl. Acad. Sci. USA 77:3649-3653.

Nikolić, J. A., O. Nedić, H. Samanc, S. Aleksić, B. Miscević, and M. Kulcsár. 2001. Peripheral circulating insulin-like growth factor-I and -II in cattle. Acta Vet. Hung. 49:53-63.

Piechotta, M., K. Kedves, M. G. Araujo, A. Hoeflich, F. Metzger, M. Heppelmann, A. Muscher-Banse, C. Wrenzycki, C. Pfarrer, H. J. Schuberth, M. Hoedemaker, H. Bollwein, and M. Kaske. 2013 Hepatic mRNA expression of acid labile subunit and deiodinase 1 differs between cows selected for high versus low concentrations of insulin-like growth factor 1 in late pregnancy. J. Dairy Sci. 96:3737-3749.

Rajaram, S., D. J. Baylink, S. Mohan, J. L. Pettis, and M. Veterans. 1997. Insulin-like growth factor-binding proteins in serum and other biological fluids: Regulation and functions. Endocr. Rev. 18:801-831. 
Rantala, M. H., M. Mutikainen, G. Schuler, T. Katila, and J. Taponen. 2014. Endometrial expression of progesterone, estrogen, and oxytocin receptors and of $20 \alpha$-hydroxysteroid dehydrogenase and cyclooxygenase II 2 and 5 days after ovulation in induced short and normal estrous cycles in dairy cows. Theriogenology 81:1181-1188.

Renaville, R., M. Hammadi, and D. Portetelle. 2002. Role of the somatotropic axis in the mammalian metabolism. Domest. Anim. Endocrinol. 23:351-360.

Rico-Bautista, E., A. Flores-Morales, and L. Fernández-Pérez. 2006. Suppressor of cytokine signaling (SOCS) 2, a protein with multiple functions. Cytokine Growth Factor Rev. 17:431-439.

Roh, S. G., N. Matsunaga, A. Miyamoto, S. Hidaka, and H. Hidari 1997. Competitive enzyme immunoassay for bovine growth hormone. Endocr. J. 44:195-198.

Romano, G., K. Reiss, X. Tu, F. Peruzzi, B. Belletti, J. Y. Wang, T. Zanocco-Marani, and R. Baserga. 2001. Efficient in vitro and in vivo gene regulation of a retrovirally delivered pro-apoptotic factor under the control of the Drosophila HSP70 promoter. Gene Ther. 8:600-607.

Spicer, L. J., E. Alpizar, and S. E. Echternkamp. 1993. Effects of insulin, insulin-like growth factor I, and gonadotropins on bovine granulosa cell proliferation, progesterone production, estradiol production, and(or) insulin-like growth factor I production in vitro. J. Anim. Sci. 71:1232-1241.

Spicer, L. J., W. J. Enright, M. G. Murphy, J. F. Roche, and C. Meath. 1991. Effect of dietary intake on concentrations of insulinlike growth factor-I in plasma and follicular fluid, and ovarian function in heifers. Domest. Anim. Endocrinol. 8:431-437.

Thangavel, C., and B. H. Shapiro. 2007. A molecular basis for the sexually dimorphic response to growth hormone. Endocrinology 148:2894-2903.
Tollet-Egnell, P., A. Flores-Morales, A. Stavréus-Evers, L. Sahlin, and G. Norstedt. 1999. Growth hormone regulation of SOCS-2, SOCS3 , and CIS messenger ribonucleic acid expression in the rat. Endocrinology 140:3693-3704.

Tuggle, C. K., and A. Trenkle. 1996. Control of growth hormone synthesis. Domest. Anim. Endocrinol. 13:1-33.

Valentinis, B., and R. Baserga. 2001. IGF-I receptor signalling in transformation. Mol. Pathol. 54:133-137.

Wathes, D. C. 2012. Mechanisms linking metabolic status and disease with reproductive outcome in the dairy cow. Reprod. Domest. Anim. 47(Suppl 4):304-312.

Wathes, D. C., Z. Cheng, M. A. Fenwick, R. Fitzpatrick, and J. Patton. 2011. Influence of energy balance on the somatotrophic axis and matrix metalloproteinase expression in the endometrium of the postpartum dairy cow. Reproduction 141:269-281.

Winkelman, L. A., M. C. Lucy, T. H. Elsasser, J. L. Pate, and C. K. Reynolds. 2008. Short communication: Suppressor of cytokine signaling-2 mRNA increases after parturition in the liver of dairy cows. J. Dairy Sci. 91:1080-1086.

Xu, J., A. J.-M. Bekaert, J. Dupont, S. Rouve, I. Annesi-Maesano, C. D. De Magalhaes Filho, L. Kappeler, and M. Holzenberger. 2011. Exploring endocrine $\mathrm{GH}$ pattern in mice using rank plot analysis and random blood samples. J. Endocrinol. 208:119-129.

Yonezawa, T., K. Mogi, J. Y. Li, R. Sako, K. Yamanouchi, and M. Nishihara. 2005. Modulation of growth hormone pulsatility by sex steroids in female goats. Endocrinology 146:2736-2743.

Zhu, T., E. L. Goh, R. Graichen, L. Ling, and P. E. Lobie. 2001. Signal transduction via the growth hormone receptor. Cell. Signal. $13: 599-616$ 